\title{
Efektivitas Penerimaan Santri Baru Melalui Sosial Media
}

\author{
Muhammad Rizaldi Pratama* \\ Prodi Komunikasi Penyiaran Islam, Fakultas Dakwah, Universitas Islam \\ Bandung, Indonesia. \\ *rizaldimuhamad7@gmail.com
}

\begin{abstract}
The phenomenon of social media presence as a result of the extraordinary development of information and communication technology. With a variety of services that can be used, social media can change the way we communicate. The Baitul Hidayah Islamic Boarding School is one of the schools that aims to share information and try to use social media as a communication tool in spreading its activities. Through the research conducted by the author on the effectiveness of attracting new students through social media, the background to the problem was found as follows: What publications were implemented in The Baitul Hidayah Islamic boarding school in the recruitment of new students. The purpose of this study is to know the publications that are made at The Baitul Hidayah Islamic Boarding School in the recruitment of new students. To find out how the process of admission of new students to the Baitul Hidayah Islamic Boarding School is carried out. To find out the effectiveness of disseminating students' activities in the Baitul Hidayah Islamic School through social media. The research method used is the quantitative method with uses and effects theory and it uses data collection techniques through questionnaires, documentation and interviews. The data analysis technique used is validation test, reliability test and normality test. The research method used is the quantitative method with uses and effects theory and it uses data collection techniques through questionnaires, documentation and interviews. The data analysis technique used is validation test, reliability test and normality test. The results of the research show that the student activities dissemination program for recruiting new students is very effective, and the student activities dissemination shows that obtained based on the outputs of the analysis, and the data derived from the research results indicate that the dissemination of student activities has an impact on the employment of new students.
\end{abstract}

Keywords: Effectiveness, Recruitment, Santri, Social Media.

Abstrak. Fenomena kehadiran media sosial sebagai perkembangan informasi dan teknologi komunikasi sangat luar biasa. Dengan berbagai layanan yang dapat digunakan, media sosial dapat mengubah cara kita berkomunikasi. Pondok Pesantren Baitul Hidayah adalah salah satu pesantren yang bertujuan untuk berbagi informasi menggunakan media sosial sebagai alat berkomunikasi dalam mensosialisasikan kegiatan-kegiatannya. Penelitian yang penulis lakukan mengenai Efektivitas penerimaan santri baru melalui sosial media, adapun penelitian bertujuan mengetahui publikasi apa saja yang dilakukan di Pondok Pesantren Baitul Hidayah dalam penerimaan santri baru. Untuk mengetahui bagaimana proses mekanisme penerimaan santri baru di Pondok Pesantren Baitul Hidayah. Untuk mengetahui efektivitas publikasi kegiatan santri di Pondok Pesantren Baitul Hidayah melalui media sosial. Metode penelitian yang digunakan adalah metode kuantitatif dengan teori uses and effects dengan menggunakan teknik pengumpulan data melalui kuisioner, dokumentasi, dan wawancara. Teknik analisa data yang digunakan adalah uji validasi, uji reliabilitas, dan uji normalitas. Hasil penelitian menunjukan bahwa program publikasi kegiatan santri terhadap recruitment santri baru cukup efektif, publikasi kegiatan santri menggambarkan bahwa diperoleh berdasarkan output analisisnya, data dari hasil penelitian yang menunjukkan bahwa publikasi kegiatan santri memberi pengaruh terhadap penerimaan santri baru.

Kata Kunci: Efektivitas, Penerimaan, Santri, Media Sosial. 


\section{A. Pendahuluan}

Keberadaan pondok pesantren yang semakin beragam dalam bentuk, peranan dan fungsi ini menjadikan fenomena yang cukup berarti dalam upaya membuat suatu pola yang dapat dipahami sebagai acuan untuk pengembangan pondok pesantren pada masa sekarang maupun yang akan datang.

Pondok Pesantren Baitul Hidayah adalah sebuah lembaga pendidikan Islam dengan sistem asrama, dengan pelajaran umum dan agama yang seimbang juga belajar tentang kehidupan yang islami. Mendidik santri untuk bekerja atas dasar keikhlasan yang berdasarkan atas pada kesadaran sebagai makhluk Tuhan dengan hidup penuh kesederhanaan tanpa melebihlebihkan sehingga dapat memberikan sebuah keteladanan yang baik sebagai pemimpin umat yang penuh dengan kasih sayang. Bertujuan untuk mencetak kader ulama' yang 'alim, sholeh dan menjadi pemersatu umat.

Oleh karena itu, selanjutnya dalam rangka kegiatan strategi pondok pesantren baitul hidayah dalam publikasi kegiatan santri di media sosial akan sangat mempengaruhi masyarakat pada umumnya. Dan dari uraian latar belakang di atas, maka penulis tertarik untuk melakukan penelitian yang berjudul "EFEKTIVITAS PENERIMAAN SANTRI BARU MELALUI MEDIA SOSIAL (Studi kasus pada program Publikasi Kegiatan Santri di Pondok Pesantren Baitul Hidayah, Bandung)."

Adapun tujuan dalam penelitian ini adalah:.

A. Untuk mengetahui publikasi apa saja yang dilakukan di Pondok Pesantren Baitul Hidayah dalam penerimaan santri baru.

B. Untuk mengetahui bagaimana proses mekanisme penerimaan santri baru di Pondok Pesantren Baitul Hidayah.

C. Untuk mengetahui efektivitas publikasi kegiatan santri di Pondok Pesantren Baitul Hidayah melalui media sosial.

\section{B. Metodologi Penelitian}

Metode penelitian yang digunakan adalah metode kuantitatif dengan teori uses and effects dengan menggunakan teknik pengumpulan data melalui kuisioner, dokumentasi, dan wawancara. Teknik analisa data yang digunakan adalah uji validasi, uji reliabilitas, dan uji normalitas.

\section{Hasil Penelitian dan Pembahasan}

Publikasi yang dilakukan di Pondok Pesantren Baitul Hidayah dalam Penerimaan Santri Baru

Adapun kegiatan publikasi yang selama ini dilakukan Pondok Pesantren Baitul Hidayah dalam Recruitment Santri Baru yaitu seperti mempublikasikan kegiatan Pentas Seni Santri, Pekan Perkenalan Khutbatu-L-'Arsy (Masa perkenalan santri dan guru-guru terhadap Pesantren), Halaqoh Qur,an, kegiatan karate, pramuka, dan angklung, dan juga Organisasi Santri Pondok Bait Al-Hidayah (OSPBA), dan banyak lagi kegiatan santri yang tidak bisa kami sebutkan satu persatu. 
Berikut beberapa gambar kegiatan santri yang dipublikasikan di media sosial Instagram Pondok Pesantren Baitul Hidayah:

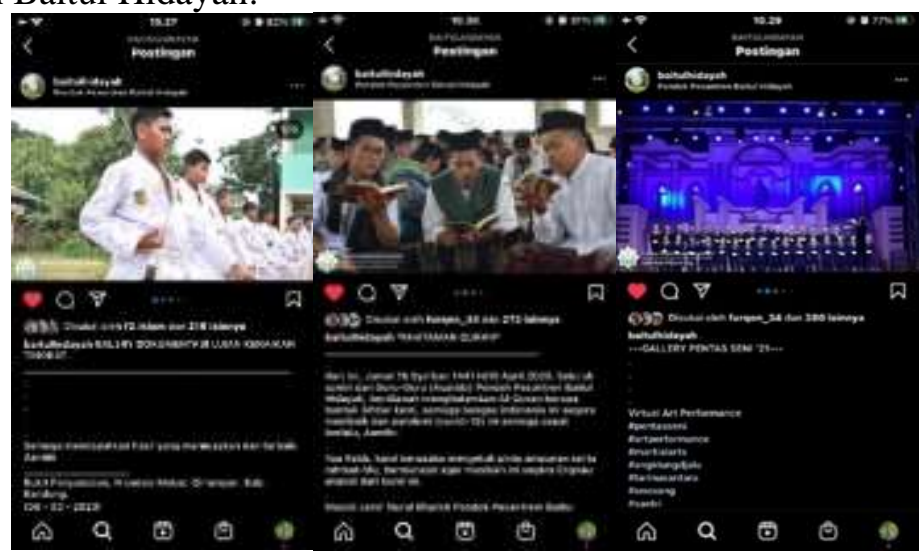

\section{Gambar 1.}

\section{Proses Mekanisme Penerimaan Santri Baru di Pondok Pesantren Baitul Hidayah}

Dalam proses mekanisme Recrutment Santri Baru Di Pondok Pesantren Baitul Hidayah, penulis telah melakukan observasi dengan salah satu pengurus pondok Baitul Hidayah yaitu Al-Ustadz Arif Rahman untuk mengetahui bagaimana tahapan mekanisme Recrutment Santri Baru yang selama ini dilaksanakan oleh Baitul Hidayah, adapun tahapan mekanisme Penerimaan Santri Baru sebagai berikut:

A. Kualifikasi Calon Santri:
1. Putra/Laki-laki
2. Beragama Islam
3. Berbadan sehat
4. Lulus Sekolah Dasar (Reguler) atau Sekolah Menengah Pertama (Intensif)
5. Bersedia tinggal di Pondok Pesantren dan mengikuti segala aturan dan disiplin.

B. Materi yang diujikan:
1. Baca Al-Qur'an
2. Imla (Dikte Arab)
3. Berhitung (ujian tulis)
4. Wawancara orang tua (WAJIB)
5. Hafalan ayat pilihan (ditentukan panitia)

C. Dokumen Yang Diserahkan:
1. Fotokopi Ijazah SD atau SMP: 1 lembar
2. Surat Keterangan Siswa Kelas 6 SD atau 9 SMP (jika ijazah belum terbit): 1 lembar
3. Fotokopi KTP orang tua: masing masing 1 lembar,
4. Fotokopi Kartu Keluarga: 1 lembar
5. Fotokopi Akta Kelahiran: 1 lembar
6. Pasfoto Calon Santri Ukuran 2×3: 2 lembar
7. Pasfoto Calon Santri Ukuran 3×4: 2 lembar
8. Surat Keterangan Sehat dari Puskemas/Dokter/Rumah Sakit: 1 lembar

\section{Efektivitas Publikasi kegiatan santri di Pondok Pesantren Baitul Hidayah melalui media social \\ Dalam menganalisis efektivitas recruitment santri baru Melalui Media Sosial yang diselenggarakan oleh Pondok Pesantren Baitul Hidayah, Bandung, maka dapat kita lihat dari keberhasilan pesantren dalam melaksanakan program Publikasi Kegiatan Santri tersebut, apakah target yang diinginkan oleh pesantren tercapai atau tidak. Dimana hal tersebut menjadi tolak ukur dalam pengukuran efektivitas.}


Cambel J.P, mengungkapkan bahwa Pengukuran efektivitas yang paling menonjol dan secara umum yaitu, Kesuksesan suatu program, kesuksesan suatu sasaran, kepuasan terhadap suatu program, tingkat output dan input, dan tujuan yang dicapai secara menyeluruh.

Dalam hal kesuksesan suatu program nya, Pondok Pesantren Baitul Hidayah menyelenggarakan publikasi kegiatan santri nya dimedia social, guna recruitment santri baru, adapun kegiatan santri tersebut seperti, Penampilan Pentas Seni Santri, Penampilan Angklung Santri, Kegiatan Perkenalan Khutbatu-L-'Arsy, Kegiatan Halaqoh Qur'an dan juga kegiatan lain nya yang penulis tidak bisa sebutkan satu persatu.

Sementara itu ukuran atau tentang pencapai tujuan dengan efektif atau tidak, sebagaimana yang diungkapkan oleh S.P Siagian yaitu, tujuan yang akan dicapai memiliki kejelasan, Strategi yang jelas dalam pencapaian tujuan, Perumusan kebijaksanaan dan proses analisis yang matang, Program disusun secara matang, Sarana dan prasana tersedia, Pelaksanaan yang efisien dan efektif, Besifat mendidik dalam sistem pengawasannya.

Berdasarkan hasil penelitian yang ditemukan, peneliti mendapatkan kesimpulan bahwa program publikasi kegiatan santri yang diselenggarakan oleh Pondok Pesantren Baitul Hidayah, Bandung, dalam recruitment santri baru cukup efektif, hal ini dapat dibuktikan dari banyaknya responden yang menyatakan sangat setuju dengan persentase sebesar 35,9\% mengatakan selalu mengomentari positif di Instagram, Facebook dan Youtube Baitul Hidayah, 39,1\% mengatakan jarang meluangkan waktu untuk membuka Instagram, Facebook dan Youtube Baitul Hidayah, $39,1 \%$ mengatakan selalu menyimak konten postingan pentas seni santri di Baitul Hidayah, 54,7\% mengatakan sangat senang belajar dan menuntut ilmu di Pondok Pesantren Baitul Hidayah, 42,2\% mengatakan sangat senang melihat kegiatan muraja'ah santri di Pondok Pesantren Baitul Hidayah dengan menumbuhkan rasa motivasi agar bisa belajar maksimal, dan 43,8\% mengatakan merasa puas ketika melihat konten kegiatan santri di Baitul Hidayah.

\section{Kesimpulan}

Kegiatan Publikasi yang dilakukan Pondok Pesantren Baitul Hidayah dalam Recruitment Santri Baru memiliki faktor pendukung dalam kegiatan dakwah dan juga recruitment santri baru, dua (2) faktor pendukung tersebut yakni:

\section{Sumber Daya Manusia (SDM)}

Yang dimakud dengan Sumber Daya Manusia disini adalah santri, guru-guru dan masyarakat yang berperan aktif dalam kegiatan-kegiatan yang diadakan pondok pesantren.

\section{Kelembagaan}

Secara garis besar, setiap kegiatan yang ada di pondok pesantren berada dibawah tanggung jawab ustadz dan pengurus yang berbeda sesuai dengan bidangnya, dalam hal ini masing-masing bagian memiliki job description yang jelas termasuk hak dan kewenangannya.

Dalam proses mekanisme Penerimaan Santri Baru Di Pondok Pesantren Baitul Hidayah, maka Pondok Pesantren Baitul Hidayah memiliki kriteria-kriteria khusus seperti bersedia tinggal di Pesantren dan mengikuti aturan disiplin, bisa membaca Al-Quran dengan baik, dan juga bisa menulis Bahasa arab dengan baik. Dan untuk proses mekanisme yang lainnya yaitu Pendataan diri pribadi masing-masing santri.

Efektivitas penerimaan santri baru Melalui Media Sosial yang diselenggarakan oleh Pondok Pesantren Baitul Hidayah, Bandung, maka dapat dilihat dari keberhasilan pesantren dalam melaksanakan program Publikasi Kegiatan Santri nya, hasil penelitian yang ditemukan, peneliti mendapatkan kesimpulan bahwa program publikasi kegiatan santri dalam penerimaan santri baru cukup efektif. 


\section{Daftar Pustaka}

\section{Buku:}

[1] Jusmaliani, Pengelolaan SumberkDaya Insani, (Jakarta : Bumi Aksara,2011), hal 76.

[2] M. Dawam Rahardjo, Pergulatan Dunia Pesantren Membangun dari Bawah, (Jakarta: P3M, 1985) hlm 2.

[3] Mastuhu, Dinamika Sistem Pendidikan Pesantren, (Jakarta: INIS, 1994), hlm. 55.

[4] Nurcholis Madjid, Bilik-Bilik Pesantren Sebuah Potret Perjalanan, (Jakarta:Paramadina, 1997), hlm. 5.

[5] Siagian Sondang. P, Manajemen Sumber Daya Manusia, ( Jakarta : Bumi Aksara)

[6] Sudjono Prasodjo, Profil Pesantren, (Jakarta: LP3S, 1982), hlm. 6.

[7] Tim Penyusun Kamus Pusat Bahasa. 2008, Kamus Bahasa Indonesia, Jakarta: Pusat Bahasa.

[8] Wahjoetomo, Perguruan Tinggi Pesantren, (Jakarta: Gema Insani Press, 1997), hlm 5.

\section{Jurnal/Skripsi:}

[1] Gusti Ngurah Aditya Lesmana, Tesis: Analisis Pengaruh Media Sosial Twitter Terhadap Pembentukan Brand Attachment (Studi: PT. XL AXIATA), ( Program Magister Manajemen, Fakultas Ekonomi, Universitas Indonesia). hal, 10-11

[2] Muhammad Irwan Padli Nasution, "Strategi Pembelajaran Efektif Berbasis Mobile Learning Pada Sekolah Dasar" dalam Jurnal Iqra', No. 1, Vol. 10, Tahun 2016, hlm. 5.

\section{Internet:}

[1] Pengertian Efektivitas dan Landasan Teori Efektivitas, admin, dalam http://literaturbook.blogspot.com/2014/12/pengertian-efektivitas-dan-landasan.html, diunduh 01/06/21 pukul 11.53

[2] www.baitulhidayah.org. 